\title{
DEGRADATION OF THE REFLECTANCE PROPERTIES OF SOME GSS IN SPACE, PRELIMINARY RESULTS
}

\author{
P.P.Sukhov ${ }^{1}$, K.P.Sukhov ${ }^{2}$ \\ ${ }^{1}$ Astronomical Observatory of the I. Mechnikov Odesa National University, \\ Odesa, Ukraine \\ ${ }^{2}$ National Space Facilities Control and Testing Centre, Ukraine
}

\begin{abstract}
A spacecraft in near-Earth orbit is exposed to extreme environmental factors, such as high vacuum, zero gravity, collisions with meteors and orbital debris, corpuscular and electromagnetic radiations, etc. These factors result in changing properties of spacecraft surfaces which leads to changes in mechanical, optical, electrical and physical properties of materials and elements of spacecrafts. This paper presents experimental data obtained from ground-based photometric observations of several geostationary satellites (GSS) built on different types of buses, starting from the beginning of their operational lives and during several years after their launches. It has been experimentally proved that spectral reflectance properties of the satellite surface materials undergo gradual degradation with time of the satellite's stay in space. Noticeable changes in spectral reflectance properties of GSS make it possible to detect damages to the satellite external payload. Comparison of changes in the reflective characteristics of different platforms over time can show the level of technical and scientific progress of spacecraft designers.
\end{abstract}

АНОТАЦІЯ. Космічний апарат, що знаходиться на навколоземній орбіті, піддається впливу цілого комплексу чинників: глибокий вакуум, невагомість, зіткнення 3 метеоритами i частинками штучного походження, корпускулярне i електромагнітне випромінювання різних видів і т.д. В результаті змінюються властивості поверхні, що призводить до зміни механічних, оптичних i електрофізичних характеристик матеріалів i елементів космічного апарату. У статті представлені експериментальні дані, отримані 3 наземних фотометричних спостережень декількох геостаціонарних супутників 3 різними типами платформ 3 моменту початку роботи супутника і через кілька років після початку роботи. Експериментально підтверджено, що спектральна відбивна здатність матеріалів поверхні супутника поступово деградує в залежності від часу перебування в космосі. За значної зміни спектральних відбивних характеристик геостаціонарного супутника можливо визначити пошкодження зовнішньої корисного навантаження супутника. Порівняння змін відбивних характеристик різних платформ 3 часом може показати рівень технічного та наукового прогресу конструкторів космічних апаратів.

\section{Introduction}

Studying the effects of the harsh space environment on the optical properties of materials is a topical and challenging issue of great interest to not only designers and engineers of space-based systems. According to expert data, the space environment effects contribute significantly to breakdowns, failures and malfunctions in spacecraft operations [1].

The following key factors affect a spacecraft's surface in the space environment:

Meteoric dust and solid particles of orbital debris that affect optical properties of the surface;

Temporal effect of ageing (degradation) of the materials covering a spacecraft's surface and solar arrays under high-vacuum conditions;

Different types of radiations affecting photo-voltage of solar arrays, especially when solar flares occur or when the spacecraft travels through the Van Allen radiation belts. Exposure to high-energy electrons results in the breaking and reforming of physical and chemical bonds;

Extreme temperature variations due to continuous transition of the orbiting spacecraft body from excessive cooling in dark portions of its orbit to heating when illuminated by the Sun, and vice versa. It results in destruction of mechanical fasteners used to mount elements of solar arrays, payload and bus (platform), as well as joints between these components.

There have been a huge number of publications and manuscripts on the subject of space materials science [1, 2, 3, etc.]. However, all these papers, with the exception of [4], present theoretical findings or results obtained under laboratory conditions not allowing for the atmospheric effects [5]. The paper by A. Didenko [4] presents experimental data on the spacecraft surfacecoating ageing with time for the period of four and a half years for three types of GSS, namely Horizont, Raduga and Intelsat, obtained during ground-based observations through Earth's atmosphere. As is commonly known, Earth's atmosphere distorts the light rays, especially 
colour characteristics of light, which change with time of the GSS stay in the space environment.

Availability of the results of long-term ground-based multicolour photometric observations of one and the same GSS makes it feasible to detect variations in the reflectance properties of the satellite. To solve this problem, it is necessary to have a database of photometric ground-based observations that should be expanded and updated for many years. Such a database was created at the Astronomical Observatory of the I. Mechnikov Odessa National University with 2004. It contains more than 2,000 sets of observational data for satellites of many classes operated by different GSS operators throughout the world.

In this paper, we present and discuss variations in the spectral reflectance index over a period of seven years orbiting in the space environment for the following GSS built upon the European bus Eurostar 3000: Astra 2E, and Express AM7. Observations of Sicral 1B on the GeoBus platform (ItalSat-3000), began 2 years later, when the IGSS began its work at the sub-satellite point.

Photometric observations of GSS enable to detect diurnal, seasonal and annual brightness variations. The causes of variations in the satellite brightness are described in detail in the studies [6 and 7]. It is known that spectral optical properties of the satellite surfaces are defined by the spectral reflectance index. In this case, the spectral reflectance index $\left(\gamma_{\lambda}\right)$ coincides with geometric albedo.

It is known that the spectral-band brightness of a spacecraft $m_{\lambda}$ is defined by formula [4]:

$$
m_{\lambda}=m_{\lambda}^{\Theta}-2,5 \lg \left[\frac{S \gamma_{\lambda} F(\psi)}{d^{2}}\right]
$$

where $m_{\lambda}^{\Theta}$ is the Sun's brightness in the respective spectral band $(\mathrm{B}, \mathrm{V}, \mathrm{R}) ;\left(\gamma_{\lambda}\right)$ is the spectral reflectance index; $\left(S \gamma_{\lambda}\right)$ is the apparent effective reflecting area of the satellite surface; $d$ is the distance to the satellite, which is known for GSS; $F(\varphi)$ is a function of phase which is analytically solved for simple geometric shapes (plate, sphere, cone, etc.).

Constant or calculated values in formula (1) are as follows: the satellite brightness, the Sun's brightness, distance to the satellite, function of phase and size (dimensions) of the satellite (if known).

If the satellite dimensions are not known, as is the case for Sicral $1 \mathrm{~B}$, it is possible to set dimensions similar to those typical for a certain class of GSS which can be adopted from different sources. In any case, the pattern of changes in the spectral reflectance indices becomes apparent. Taking into account that the dimensions of an active satellite are invariable over many years of its operation, it must be the spectral reflectance index $\left(\gamma_{\lambda}\right)$ to change. A. Didenko in the study [4] suggested calculating relative reflection indices $\Delta \gamma_{(\mathrm{B}-\mathrm{V})}$ and $\Delta \gamma_{(\mathrm{V}-\mathrm{R})}$. The authors embraced the idea and suggested studying variations in the spectral reflectance indices $\left(\gamma_{\mathrm{b}}, \gamma_{\mathrm{v}}, \gamma_{\mathrm{r}}\right)$ as a function of time.

\section{Results of observational data processing}

The figures below depict variations in $\Delta \gamma_{(\mathrm{B}-\mathrm{V})}$ and $\Delta \gamma_{(\mathrm{V}-}$ R) for the GSS Astra 2E (at the sub-satellite point $28^{0} .5 \mathrm{E}$ ),
Express AM7 (at the sub-satellite point $40^{\circ} .0 \mathrm{E}$ ) and the GSS Sicral $1 \mathrm{~B}$ at the sub-satellite point $11^{0} .8 \mathrm{E}$.

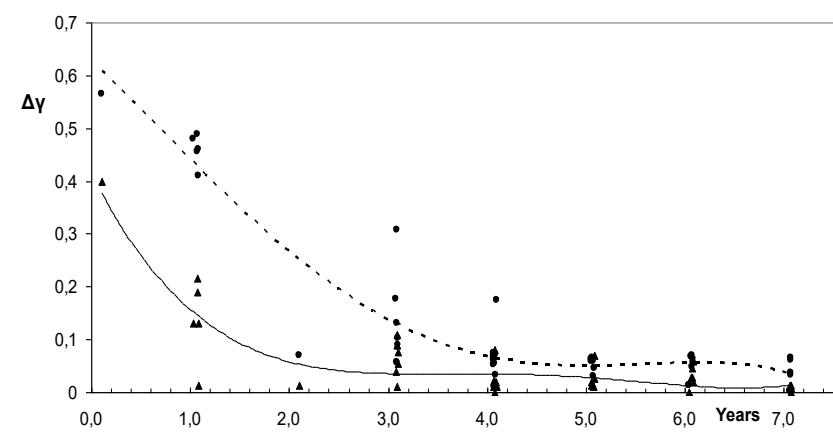

Figure 1: The GSS Astra 2E. Changes $\Delta \gamma_{(\mathrm{B}-\mathrm{V})}-$ solid line; $\Delta \gamma_{(\mathrm{V}-\mathrm{R})}-$ dotted line. Began observations from the moment the sub-satellite point was reached in 2013.

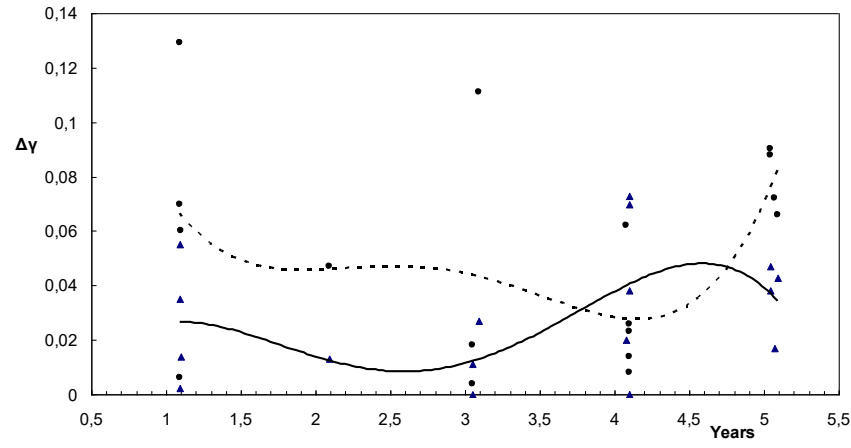

Figure 2: The GSS Express AM7. Changes $\Delta \gamma_{(\mathrm{B}-\mathrm{V})}-$ solid line, $\Delta \gamma_{(\mathrm{V}-\mathrm{R})}-$ dotted line. Began observations from the moment the sub-satellite point was reached in 2017.

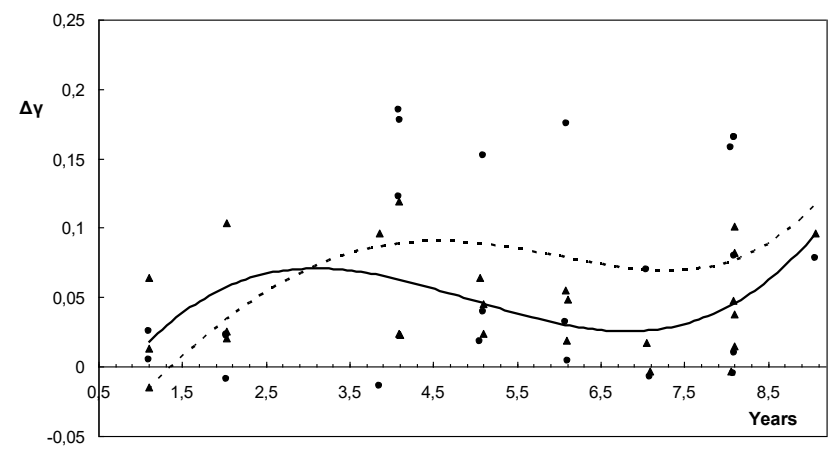

Figure 3: The GSS satellite Sicral 1B. Changes $\Delta \gamma_{(\mathrm{B}-\mathrm{V})}-$ solid line, $\Delta \gamma_{(\mathrm{V}-\mathrm{R})}-$ dotted line. Was launched on the orbit in 2009. It was monitored began after two years of operation at the sub-satellite point.

\section{Conclusions}

Geostationary satellites Astra 2E have been observed from the start of their in-orbit operation. For this GSS, variations in $\Delta \gamma_{(\mathrm{B}-\mathrm{V})}$ and $\Delta \gamma_{(\mathrm{V}-\mathrm{R})}$ were noticeable during the first three years of observations. For GSS Sicral 1B whose observations started two years after launch, such a correlation is practically insignificant. For this GSS, negative quantities are observed $\Delta \gamma$.

The Russian communications satellite Express AM7 showed no significant changes in reflectivity. It probably 
has a nice modified platform and solar panels compared to the Astra 2E.

It should be noted that all observed objects do not change their reflective characteristics in the same way.

The obtained relations $\Delta \gamma_{(\mathrm{B}-\mathrm{V})}, \Delta \gamma_{(\mathrm{V}-\mathrm{R})}$ can serve as a medical record describing the medical history, that is, the health of a satellite's surface. Noticeable changes in these characteristics make it possible to detect damages to the GSS external payload. Comparison of changes in the reflective characteristics of different platforms over time can show the level of technical and scientific progress of spacecraft designers. Our database contains sets of observational data for GSS of many classes operated by different states, including Azerbaijan, Bulgaria, Belarus, Greece, China, Turkey, Russia, USA, India, Italy, France, Israel, ESA etc.

\section{References:}

1. Novikov L.S.: 2014, Kosmicheskoye materialovedeniye, M.: Maks Press.
2. Kulikov V.M., Ladygin Ye.A. et al.: 1980, Deystviya pronikayushchey radiatsii na izdeliya elektronnoy tekhniki, M.: Sov. Radio.

3. Kreynin L.B., Grigor'yeva G.M.: 1979, Itogi nauki $i$ tekhniki. Issledovaniya kosmicheskogo prostranstva, 13, M.: VINITI.

4. Didenko A.V.: 2005, Vestnik Kazakhskogo natsional'nogo pedagogicheskogo universiteta im. Abaya. Seriya «Fizikomatematicheskiye nauki», № 1(12), 81.

5. Engelhart D.P., Cooper R., Cowardin H., Maxwell J., Plis E., Ferguson D., Barton D., Schiefer S., Hoffmann R.: 2019, The Journal of the Astronautical Sciences, 66, 210. DOI: 10.1007/s40295-019-00175-2.

6. Didenko A.V., Usol'tseva L.A.: 1987, Trudy AFI AN KazSSR, 48, 112.

7. Sukhov P.P.: 2014, Kínematika i fizika nebesnikh tel, 30, № 2,72 . 